\title{
Students' Use of English in German Lessons
}

\author{
Miroslav Janík \\ Masaryk University, Faculty of Education
}

\begin{abstract}
In language learning, teachers often encounter multilingualism when teaching a specific language. Multilingualism is the ability to use languages in an interconnected way; languages as such can be thus approached rather as a linguistic repertoire. In this study, we look at how students (and teachers) in Czech schools deal with English use within German lessons. In this context English is the first foreign language taught to students and German the second foreign tongue taught in school. Twenty-eight lessons from four experienced language teachers were recorded at lower-secondary level. Conversational analysis of transcripts identified 65 instances of English use in German classes. The analysis suggests that English is used in three ways, either it is seen as a source of a problem that needs to be repaired, it is accepted practice, or the use of English is initiated by the teacher. Our analysis suggests that using English language in German lessons and potentially multilingualism in teaching does not have a clearly defined status. Furthermore, inconsistency in teacher responses to multilingualism may require clearer consideration as to if languages are taught as discreet entities or more flexible linguistic mechanisms may be adopted to facilitate learning.
\end{abstract}

Keywords: multilingualism, foreign language teaching, usage-based SLA, language practices, conversation analysis

In modern society, with global communication, widespread migration and media access, few people can say they live in strictly monolingual environments and speak only "one language" (Busch, 2012a). Different languages, parts of languages, and dialects, for example, are a part of everyday life and make up our linguistic repertoire for various everyday situations. In this study, we focus on the dynamic use of languages that are learned and used within school environments.

In the first part of this study we introduce the concept of languages as a linguistic repertoire. As the focus is on the languages that students learn in school, which for this project is English as the first foreign language and German as a second foreign language, we introduce the usage-based perspective on second language acquisition (SLA) and discuss limits and opportunities of using more languages in foreign language teaching.

In the second part, the methodology will be introduced, including the analytical procedure (conversation analysis; CA) and the unit of analysis. It is assumed that CA offers an appropriate insight into the microstructures of interactions between 
86 the teacher and the student(s), but CA also allows us to display some features of language policy that are established in the classroom.

In the next part, the results will be presented. When interpreting the results, we take into account not only language policy, but also the institutional context, i.e. the roles of the teacher (e.g. as language policy maker) and the students that are set by the "school" as an institution and its influences on interaction. In the last part, our results will be discussed with respect to language teaching and language policy.

\section{Languages and multilingualism}

In this study, it is assumed that no one is monolingual and that everyone is "equipped" with a specific range of for example, languages, dialects, varieties, and routines (Busch, 2012b). A speaker, to produce social meaning, uses this linguistic repertoire. According to Gumperz (1964, p. 137), linguistic repertoire can be understood as the 'tools' of everyday communication. Speakers choose from this toolbox in accordance with the meanings they wish to convey. Furthermore, social occasions limit the participants in their communication and more importantly, limit the kind of social relationships that may be brought into play (Gumperz, 1964). Moreover, the use of languages is in this study understood as an example of social practice, based on Vygotskian socio-cultural theories.

There are two contrasting views on language - that of languages as isolated systems with strict rules as proposed by de Saussure or Chomsky, and that of languages as a systems with heterogeneous constructions, each with affinities to different contexts and in constant adaptation to usage (Bybee \& Hopper, 2001; Lewis, Jones, \& Baker, 2012). Our research perspective is not focused on static structures such as syntax, grammar, lexica or on the influence of one language upon another but rather on the dynamic and heterogeneous composition of linguistic repertoires.

There are many approaches to studying the usage of languages as dynamic and/ or fluid entities, each underlining a specific domain but with some crossover in approaches. For instance, the term translanguaging, which is rooted in Vygotskian sociocultural theories, refers to the dynamic nature of multilingual practices (García, 2009; Canagarajah, 2012). The concept of heteroglossia highlights the multilinguality, the multivoicedness and the multidiscursivity of society. It can be characterised as the awareness of diversity not only in the sense of a multitude of separate and bounded language communities but also within a community, within a network of communication or within a given situation (Bakhtin, 1981; Busch, 2010). The term translingual practice describes the dynamic language manners not only in oral, but also in written production, predominantly in academic contexts (Canagarajah, 2012). Transidiomatic practices refer to the communicative practices of transnational groups that interact using different communicative codes simultaneously present in a range of local and distant communicative channels 
(Jacquemet, 2005). The concept of fluid practices of language in urban contexts, known as metrolingualism, rejects the idea that there are discrete languages or codes (Otsuji \& Pennycook, 2010; García, 2014). In this study, we will not focus upon any specific concept; the emphasis rather is placed on the dynamic nature of language practices.

In the context of languages and multilingualism in education or schools, three dimensions of research interests are identified (Vetter, 2013). Firstly, it is the awareness and recognition of the linguistic resources available with respect to multilingualism, such as language policy or national strategies (Krzyzanowski \& Wodak, 2011; Johnson, 2010). Secondly, the instruction and learning in language/s (classroom practice, language for specific purposes, translanguaging in instruction: Blackledge \& Creese, 2009; Bonacina-Pugh, 2012; Makalela, 2015). Finally, foreign language teaching is of interest to the research community (Henry \& Apelgren, 2008; Dewaele \& Thirtle, 2009). In this study we combine the perspective of foreign language teaching and the perspective of instruction and learning in languages, because our aim is to describe language practices during teaching of foreign language. We assume, that the dynamic use of student's repertoire (hereafter referred to as languages) is natural part of student's learning and acquisition ${ }^{1}$ of languages. For this reason we explain the usage-based perspective in context second language acquisition and furthermore we discuss some limits of language use set by language policy on the one hand, while on the other hand we indicate, how opportunities of using more languages can be established.

\section{Usage-based perspective: use of more languages during instruction}

The usage-based perspective of thinking about language teaching and learning is linked to the social turn in SLA (Firth \& Wagner, 1997). The social turn reflects the critique on cognitive-based SLA in a sense that it does not provide sufficient theoretical and methodological instruments that could describe processes of language learning (Klein, 1998). The heaviest critique is led against what Klein (1998) termed "target deviation perspective" that consider "native language" as an undiscussable requirement for second language.

The perspective of the social turn underlines specific way of learning a second language(s) respecting individual needs of learners and social situation. Although social factors were always part of SLA explanations, the social turn is marked by identification of interaction as a key concept for language development (Long, 1981).

Research in field of SLA respecting the social turn has led to a need to redefine its key concepts. Cognition is understood as a two or more way process and it is embodied in Vygotskian socio-cultural theories. Grammar has been reconstructed

1 With regards to Könings (2010) in this study we use terms foreign language acquisition and learning synonymously. 
as meaning making and as meaning construal in cognitive linguistics. Interaction has been redefined as socially distributed (accomplished in conversation analysis) while learning has been investigated as social apprenticeship in language socialisation theory and self-concept has been reconceptualised in identity theory as socially constructed and contesting positioning for being in the world (Ortega, 2013).

\subsection{Limits and opportunities of the use of more languages}

In this study, it is assumed that language use in the classroom is influenced by multiple factors, from the disposal linguistic repertoire of the children to language policies on different levels. As we have languages, we focus on the setting limits of language use in the classroom and on creating opportunities to use more languages that are set by the teacher. Within this study, the term teacher is used for the reference to the language teacher.

As an umbrella term for processes of setting limits into the language use we consider in this study the concept of language policy. The term language policy refers to many processes linked to the state power and its efforts to regulate the use of languages. In the context of education, language policy is connected to language planning (Coulmas, 1985) and ideology (Woolard, 1992). Considering language policy in teaching context, the extension of the term is apparent - language policy can be understood as all forms of influencing languages in schools and in classrooms.

Based on this presumption, the teacher can be considered an enactor of the language policy in the classroom. This means that teachers make their own language policy trough appropriation. Appropriation refers to the ways in which enactors interpret and take in policy elements, thereby incorporating these discursive recursive resources into their own directions of motivation, interest, and action (Levinson et al., 2009, p. 779).

Understanding teachers as language policy enactors requires recognition of policy as processes that are embedded in ideologies concerning languages, and in the teachers' own sense of usability and reasonability of policy, and in their notion of second foreign language teacher professionalism. In the context of teacher professionalism, didactic concepts that build on using more languages in teaching a second foreign language have been designed. Those programmes and concepts assume that multilinguals select features and (co-)construct their language practices - from a variety of their linguistic repertoire and relational contexts - to fulfil their communicative needs (cf. Hufeisen, 2010, p. 377). Using more languages and supporting of using more languages is from this perspective seen as opportunity to communicate but also to learn languages.

An example of such a programme is the concept of third language didactics (Tertiärsprachendidaktik). It focuses on learning languages additively, but it stresses respecting and making use of previously acquired languages (Hufeisen \& Neuner, 2003). The concept of intercomprehension on the other hand, concentrates on teaching (especially receptive skills) of more languages from one language family 
together (Bär, 2009). There are also plurilingual education programmes that are based on the dynamic use of languages during teaching (García \& Kleifgen, 2010).

\subsection{Language use from the research perspective}

Overall research in the field of multilingualism in education shows that using multilingual resources can positively affect learning environment of students and can contribute to positive schooling experience (García, 2009; Wei, 2011). For instance Makalela (2015) has shown, that using multilingual (originally translanguaging) practices in preparing pre-service teachers for multilingual classrooms has both cognitive and social advantages that are not typically associated with monolingual classroom interaction. The pre- and post- achievement tests have all shown that translanguaging strategies are effective in increasing the vocabulary pool of multilingual speakers. While the reflective accounts of the study participants revealed that breaking boundaries between a range of linguistic resources in multilingual classrooms affords the students a positive schooling experience and affirms their multilingual identities.

Becoming multilingual during schooling at a specific age brings specific issues into the language learning research. Special ways of language use by bilinguals, who learned their second language (L2) post-puberty and became writers and scholars in this language, were investigated by Pavlenko (1998). In her qualitative study she focuses on the relationship between languages and selves. By using autobiographic narratives she examines subsequent stages of second language learning (SLL) and the person's current positioning. Based on the data source an argument is presented for new metaphors of SLL, new approaches to SLL, and for the existence in some cases of two stages of SLL: a stage of losses and a stage of gain, with specific substages within.

As language use is often restricted in instruction because of set language policies in the classroom, the teacher adopt the role of a language policy maker, and these processes are also reflected in research. Stritikus (2003) in his case study examined the processes of how literacy and language policy get translated into classroom practice. Such processes are described by a variety of factors which have been used in policy research to explain variations in policy implementation such as the nature of the local school context, the beliefs and experience of the teacher, and ways in which the teacher might learn from a new policy context. Such a perspective brings the dynamic roles into focus that teachers play in the enactment of educational policy, and the manner in which practice may shift with time.

Furthermore, the way in which and when languages are used in school context is linked to didactic methods and procedures. It has been demonstrated that numerous alterations in the participants' orientations to social identities and both internal and external discourse occur (Kasper, 2004). The study highlighted the payoffs of an emic microanalytical focus, attending jointly to locally produced actions and membership categories as they are made relevant by the participants in the sequential unfolding of the interaction. The conversation analysis methodology allowed the authors to 
90 document in detail how a very weakly defined task was transformed into a complex hybrid activity by the participants.

The usage-based research in SLA is often focused on learning $L 2$ and the research of multilingualism in the context of social turn concentrates on multilingual learning environment and the social impact of using different languages during teaching. In this study, however, we investigate what teaching situations look like in the so-called third language classroom where multilingualism is ensured by the fact that students have already learned to some degree a first foreign language.

\section{Methodological considerations and procedure}

As aforementioned, this study focuses on language practices in second foreign language teaching. The aim is to describe teaching situations using German as a second foreign language example in which students' use of English as first foreign language is evident. It should be pointed out that this study only takes into account languages learnt at school (specifically English and German) and cannot include non-school based language learning and use.

The main research question is how teaching situations are organised in which the students' use of the first foreign language (English as L2) in the second foreign language lessons (German as L3) is evident.

\subsection{Research sample}

The research sample consists of 28 videotapes and transcripts of lessons of German as a second foreign language at lower-secondary schools in the Czech Republic (children aged circa 10 to 14). Seven teachers participated in the study - four lessons were videotaped for each teacher ${ }^{2}$. The data was collected in 2012 as part of the research project IRSE Videostudy in schools in the South Moravia region. Participating schools were randomly selected. Informed consent was obtained from all participating teachers and from parents of all students.

All the students in the research sample had been learning German less than 2 years prior to this study at school as a second foreign language (with English being their first foreign language). The teachers from our sample self-assessed their English to be between A2 and B2 level (Common European Framework..., 2001). Their teaching experience for German ranged from 9 to 20 years.

\subsection{The unit of analysis and research method}

The unit of analysis in this research is termed the teaching situation. The term situation is generally not used as a "terminus technicus" in research (Deppermann

2 Teachers are labelled by letters A-G, the order of lessons by numbers 1-4. 
\& Spranz-Fogasy, 2001, p. 1148). In this study, the ethnomethodological perspective of situation is emphasised, which posits that in a situation, meaning is shaped and socialisation takes place (Schütze, 1987, p. 161). A teaching situation is understood as a thematically cohesive part of instruction in which interaction between the teacher, the student(s) and the educational content is evident (cf. Janík et al., 2013). A situation consists of several turns or sequences.

The focus of our research is, however, only on such situations in which students' use of English in the lessons of German as a third language is evident. This broad definition includes all instances of use of English (or fragments of English), be it English pronunciation in a German word, students' use of an English word when the German word is beyond their knowledge, or when the use of English is initiated by the teacher.

Conversation analysis (CA) allows researchers to examine communication relatively independently of external factors and predefined structures. This means that CA can help us understand processes in a conversation solely from within the conversation itself. Although CA is considered primarily a linguistic (or sociolinguistic) method, its interest lies not in linguistic forms themselves, but rather in the way in which they are used to embody and express subtle differences in social actions. The fundamental CA questions are: Why this, in this way, right now? (Seedhouse, 2004). Furthermore, CA is interested in the emic perspective of social reality, i.e. the perspective of members of the interaction (ten Have, 2007). This does not mean CA does not use technical vocabulary such as adjacency pairs, turn-taking, preference organisation or repairs, but this terminology refers to members' knowledge-in-use. Knowledge-in-use can be understood as members' method to realise interaction or knowledge its procedural infrastructure.

Two approaches to CA are distinguished, basic CA as proposed by Sacks, Schegloff, and Jefferson, and institutional CA (Heritage, 2005). In institutional CA, the actors of conversation hold a specific role and corresponding identities such as patient/ doctor, customer/waiter or student/teacher. Moreover, the institutional context provides a specific framework which establishes the typical language procedures (Drew \& Heritage, 1992). In our study, approaches of institutional CA were used.

\subsection{Conversation analysis in research on second language acquisition and multilingualism}

CA has been used to study interactional processes in foreign language teaching, often within the realm of second language acquisition (SLA). SLA is often used as an umbrella term for learning and teaching of the additional language(s), however, there are differences between foreign language teaching, learning and acquisition (Königs, 2010). Scholars using CA in the context of SLA tend to focus primarily on structures that show how languages are learned or acquired in interaction while an active role of all participants in interaction is presupposed (Markee \& Kasper, 2004). This means that students are seen as active actors of communication in the classroom who transform tasks in interactional teaching situations just by entering the communication 
92 itself (cf. Coughlan \& Duff, 1994). Studies that focus on multilingualism and use CA attempt to describe how and why multilinguals switch their languages and how they use their linguistic repertoire in conversation (Gracía \& Wei, 2014; Cashman, 2010). Use of languages is dependent on the specific contextualisation cues and social conventions (Gumperz, 1982).

\subsection{Research design}

This study was realised in three phases. In the first phase, data collection procedures were designed, permissions obtained and the data (videos and contextual information) was collected. In the second phase, the videodata was transcribed in Videograph programme (Rimmele, 2002) and situations where students use English were identified. Due to the nature of teaching situations it is difficult to pinpoint the exact start and end of a situation. In this study, the start of a situation is defined as the first turn that is connected to a sequence with students' evident use of English. The end of a situation is located where actors leave off responding to previous turns and change topic. The identified situations were subsequently transcribed in transcription system GAT2 (Selting et al., 2009), which is suited for conversation analysis as it provides more details than simple transcription in Videograph. In the third phase, the data was analysed using institutional CA. The original video recordings were reviewed during analysis multiple times to derive greater insight such as tone and context in a conversation.

\section{Results}

The focus is primarily placed on the organisation of the identified situation, in which the students' use of English is evident. In the analysis and interpretation, the context of teaching German as a third language will be taken into consideration. Altogether, we identified 65 situations, and from these we will use some situational examples and identify the key ways that other foreign languages are used in foreign language teaching.

Teaching situations containing the use of English were predominantly organised in initiation-response-feedback (IRF) structure (Mehan, 1979). The term IRE (initiation response - evaluation) has also been used in some studies but the context of use is the same (Mehan, 1979). IRF structure is seen as typical for the context of instruction (Seedhouse, 2004). It consists of three phases of interaction: initiation (such as teacher question), response, and feedback (teachers response and evaluation of students answer). IRF structure has many variations depending on the situation. These variations are often connected to students not providing the expected response and include counter questions, cluing or request for more detailed elaborations.

The following sections introduce different examples in which English has been used in German language lessons. The aim is to provide an overview about the 
structure of typical situations. The extent of each does not reflect the mathematical proportion of analysed situations.

\subsection{English seen as a problem}

In the following situations, the students' use of English is seen by the teacher as a source of a problem that needs to be redressed. In such situations, it is often the teacher who provides the repair (in CA, this is called other-initiated other repair). This appeared to be the most common ${ }^{3}$ practice in analysed situations and will be described in the next chapter.

\section{Other-initiated other repair}

English seen as problem followed by a repair (other-initiated other repair) we can demonstrate on the following example (situation 1). This situation took place during checking homework.

\section{Situation 1 (T: E_4) 4}

01 T: Ina se směje, jo? Jirko, pod'. 01 T: Ina is laughing, right? Jirka, come on.

02 S1: Ich swimming.

02 S1: Ich swimming.

03 T: Schwimme

04 S1: Schwimme ( - ) [Já plavu]

05 T: [Michale]

03 T: Schwimme

06 S2: Ihr weint

04 S1: Schwimme ( - ) [I'm swimming]

05 T: [Michael]

06 S2: Ihr weint

In his response to the teacher's cue (line 1), the student (S1) uses English (line 2) and in the following turn the teacher provides a repair in the form of recast, i.e. rephrasing of utterance with the same meaning; such as described by Long (1996) and Mackey and Philip (1998). Although the student rephrases his utterance in the next turn (line 4) and indicates this way that he has recognised the repair, the teacher does not acknowledge it and turns their attention to another student.

Recast is one of the most common reactions when a student's utterance does not comply to the teacher's expectation. The recast does not allow the student to reflect his previous utterance and seems to be not very effective way of giving a feedback (Lyster \& Ranta, 1997), however, teachers often use recast in cases of "errors" that, from the teacher's perspective, do not require intensive pedagogical intervention (Doughty, 1993).

3 The aim of this study is not to count the occurrences of the use of English language but to describe how it is realised and what it means for the interaction between the students and the teacher. The vague information about the number of situations should provide only superficial overview. Any exact sum would be misleading due to the diversity of analyzed teaching situations.

4 Author's translation into English is provided. The parts of the utterances originally said in German are kept in German or English. Those originally uttered in Czech are in italics. All names were anonymised. 


\section{Other-initiated self-repair}

In the next example we focus on practice where students' use of the English language is seen as source of problem, but instead of repairing the utterance, teacher requires the repair to be provided by the student themselves (other-initiated self-repair). Although in the research sample such practices were not very common, from teaching perspective they seem to be more effective for learning and reflecting languages (Lyster \& Ranta, 1997). Situation 2 illustrates such an occasion. The class is checking a completed exercise in the textbook and answering additional questions about clothing devised by the teacher.

Situation 2 (T: F_3)

01 T: Tak. ( ) antworte bitte auf Deutsch. Zkus nám odpovědět německy.

02 S1: ( )

03 T: A ještě teda, kdybys odpověděl celou větou. Chlapci s čepicí se jmenují tak a tak.

$04 \mathrm{~T}$ : < učitelka se obrací k dalšímu žákovi>> Tak, jak se řeknou chlapci?

05 S2: Boy.

06 SS: [ ((smích))

07 T: [Tak boy (. ) když už (. ) ] tak boys ist in Englisch (. ) Auf DEUTSCH,

08 S2: Die Jungen.

09 T: Die Jungen.

10 S2: Mit der Mütze.

11 T: Mit der Mütze. Jmenují.

12 S2: Heißen.

13 T: Hießen.

14 S2: ( )

15 SS: ((smích))
01 T: So. ( ) antworte bitte auf Deutsch. Try to answer in German.

02 S1: ( )

03 T: So, If you could answer with whole sentence. The names of the boys with the cap are so and so...

$04 \mathrm{~T}$ : $\quad<$ the teacher turns to another student >> So, how do we say boys?

05 S2: Boy

06 SS: [ ((laughing))

07 T: [So boy (. ) If so (. ) ] so boys ist in Englisch ( . ) Auf DEUTSCH,

08 S2: Die Jungen.

09 T: Die Jungen.

10 S2: Mit der Mütze.

11 T: Mit der Mütze. Their names are.

12 S2: Heißen.

13 T: Heißen.

14 S2: ( )

15 SS: ((laughing))

One student is answering a question; while he is thinking, the teacher is trying to help him by reformulating the requested response in Czech (line 3 ) and by breaking the question down, for example "How do we say boys"; line 4. In the following turn, the student uses English to accomplish the task. Afterwards, the teacher draws attention to the use of English and encourages the student to answer in German (line 7). In the next turn (line 8), the student "repairs" his previous answer and uses German, which is acknowledged by the teacher (line 9) by echoing the student's utterance (re- 
peat) and, in doing so, the teacher invites the student to continue with the task (so called designedly incomplete utterance; Koshik, 2002). In the next exchanges (lines 10 to 15), the student and the teacher deal with the task, but English does not appear any more. Such interactional form of collaborative step-by-step realisation of required utterance can be understood as co-operating organization (Pomerantz, 1978).

\section{Self-initiated self-repair}

In very few situations observed were students aware of the problem in their utterance that included English language and realized the repair without any external initiation (self-initiated self-repair). This practice, however, indicates awareness of languages. One of these situations occurred during the revision of months in a year (situation 3).

Situation 3 (Teacher: G_3)

01 T: Takže Patrik, Světlana, jo? Co 01 T: So Patrick, Světlana, ok? What tady ještě nebylo? Dáme si třeba ( - ) květen $=$. didn't we have? We will have for

02 S1: = Květen. example ( - ) Mai =.

03 S2: March ( - ) Mai.

04 T: Mai. Dobře.

05 S3: Ty se tady snažíš.

02 S1: = May.

03 S2: March (-) Mai.

04 T: Mai. Right.

05 S3: You are trying, aren't you.

The student is asked to translate the word May (květen) into German. When answering he uses the English word March, which he himself recognises as an inappropriate answer and immediately repairs (line 3 ). However, it is not obvious if the reason for the repair was the language choice, factual mistake or both. In the next turn, the teacher simply confirms the answer by repeating it and by using the word "right". The situation ends on line 5 by "feedback" from a classmate in the sub-floor communication in a slightly ironic tone (van Lier, 1988).

Overall our data shows that English is sometimes seen as source of a problem for teachers, but also for students. When the teacher reacts to English as to a source of a problem, they often just reformulate the student's utterance or (more rarely) require the repair by the student. When the student recognises English as a source for repair, they realise it without any initiation on the side of the teacher.

\subsection{English as accepted practice}

In many situations, no reaction to the use of English is obvious. In this study, such practice is understood as accepted language practice in the sense that participants of the interaction do not see it as problem that requires some reaction or needs to be repaired.

In the first presented situation, there is no visible reaction of the teacher or the students to the use of English in their German lesson. This situation occurred within 
96 an activity aimed at revising grammar, specifically at revising prepositions connected to countries (situation 4$)$.

Situation 4 (T: F_4)

$01 \mathrm{~T}$ : Všechna vlastně jsme si řekli $01 \mathrm{~T}$ : We said together all the cities města, mají nach a státy pokud jsou rodu středního také nach, jenom in die (tady) má čtvrtý pád. that go with nach and countries if they are in neutrum and also go with nach, only in die (here) in akusativ.

02 S1: $\rightarrow$ Nach England nach <<angl. výslovnost $>$ England $>$, in die Tschechische Republik, nach Norwegen, nach ().

02 S1: $\rightarrow$ Nach England nach $<<$ Engl. pronunciation $>$ England $>$, in die Tschechische Republik, nach Norwegen, nach ().

03 T: Ist es gut?

03 T: Ist es gut?

04 SS: Ja.

04 SS: Ja

The student's use of English (line 2) is a reaction to the task focused on prepositions (line 1). Using English is apparently not seen by the teacher and the students as influencing the adequate completion of the task and, consequently, it is not repaired by the students (line 4); there is also no reaction or confirmation of correctness from the teacher's side.

It is obvious, that using of English in such situations is seen neither as barrier for understanding the communication in the classroom, nor does it disrupt the successful completion of the task. Overall it means also that the use of English is not consistently seen as source for repair, it can by accepted be teacher as way of fulfilling the task or the way how, to a certain extent, successfully communicate.

\subsection{Use of English initiated by the teacher}

In some situations, the students do not use English spontaneously but as a reaction to a communicative need, and the use is initiated by the teacher. In such situations, English is used as legitimate language practice that should lead to utterances in German. In this study we do not consider English as interlanguage (Selinker, 1972), because English is the requested language. An example of this is a situation that took place during a class discussion in which students describe each other using German terms for colours (situation 5).

Situation 5 (Teacher G_1)

01 S1: Jak řeknu červený?

01 S1: How can I say red?

02 T: Červený?

02 T: Red?

03 S1: Ne. (. ) Jak je hnědá?

03 S1: No. (. ) How can I say brown?

04 S2: Bílý.

04 S2: White. 
05 T: No, to je jak anglicky.

$05 \mathrm{~T}$ : So, it is the same as in English.

06 S1: <<angl. výslovnost>brown>.

06 S1: << Engl. pronunciation >brown>.

07 S?: Braun.

07 S?: Braun.

$08 \mathrm{~T}$ : =Braun. Pomožte si tou angličti- $08 \mathrm{~T}$ : =Braun. You can make use of nou, když už je spousta věcí je podobná, jo?

English, as there are a lot of

things that are similar, ok?

In this situation, the students are to describe the hair colour of their classmate. Firstly, they are negotiating the colour (lines 1-3). Then the student asks the teacher for help with how to say brown in German. That can be understood as a claim of insufficient knowledge (Sert \& Walsh, 2013), but also as an expression of willing to work on the task. The teacher does not give a direct answer but he provides support by using a metalinguistic clue (line 4). From the perspective of CA, this form of cluing can be described as a kind of a counter question - that is why the student answers using English prompted by the teacher. Another student then provides the German word for brown. In the following utterance, the teacher repeats the German expression for brown again as part of giving feedback and in his following comment he draws attention to the similarities between German and English and the possibilities using English when learning. The utterance on line 4 is a fragment of sub-floor communication between the students that can be understood as a joke about the hair color of the classmate.

In most of the analysed situations, the teacher's initiation of English use usually serves as a clue when the students are, due to insufficient language knowledge, not able to complete a task. English is seen as a go-between language that can lead to the required answer in German. In almost all those situations, English was initiated in such language elements that are similar to German (e.g. some similar vocabulary) or as an illustration of certain differences (e.g. differences in pronunciation or in grammar).

To sum up this part of the study, we have shown that English in German lessons is naturally used by students in various situations. In some of them, English is seen as a source of a problem that needs to be repaired. In other situations, it is accepted or at least no reaction to using English is evident. But there are even situations identified and analysed in which English use is actually encouraged and initiated by the teacher and it contributed to student's appropriate and correct use of German language.

\section{Discussion}

In general, our study shows that using English is a natural part of teaching practice of German as a foreign language and the situations that include the use of English follow mostly the IRF structure that is common in teaching.

In situations in which the other-repair is realised by the teacher as a reaction to student's English, a so-called recast is usually used. According to some scholars, 
98 teachers usually use recast in situations when they apparently do not want to deal with the repaired utterance (cf. Mackey \& Philip, 1998). Moreover, in recast only the language form is addressed but the meaning remains. Recast thus indicates mutual understanding between the teacher and the student. From this perspective, English in German lessons is seen as an error. On the other hand, it is not seen as a structural mistake that has to be thoroughly treated. However, in other situations, another form of repair can be seen, one of the actors, instead of repairing, initiates the repair of the problematic utterance (other-initiated self-repair) ${ }^{5}$. It is not surprising that the initiation of self-repair is realised only by teachers. When initiating self-repair, teachers often provide metalinguistic clues to encourage the students' reflection on their language use (Lyster, 1998). Handling the use of English in such a way is relatively demanding and time-consuming, the use of English in such situations is seen as a problem that needs to be discussed and/or repaired. On one hand, this approach to English in German lessons could contribute to students' metalinguistic awareness. On the other hand, it could be perceived as a clear indication that language policy permits only the target language in the class. Many researchers criticise such strict separation of languages, as well as the presumption that only the target language can be used in class (Cummins, 2007; Fitts, 2009; García, 2009).

We have also shown examples of situations in which English was regarded neither by the teacher, nor by the other students as a source of a problem that needs to be repaired 6 . In such situations, English is accepted as a permitted language practice. It does not necessarily mean that the use of other than the target language was not noticed, but for certain reasons such as, a different aim of the activity, or time pressure, the use of another language did not hinder the communication or activity ${ }^{7}$.

Finally, we have pointed out that in some situations teachers elicit the use of English. In those situations, English is used as a way of reflecting on languages that should lead to better learning of German. We assume that the teachers are aware of their students' linguistic repertoire and they try to take advantage of it. In other words, they create opportunities in their teaching to use their languages to successfully fulfil the task, even though the target language is originally demanded.

This study, as well as previous research, describes how in language education practice, languages are used flexibly. However, this flexibility is sometimes random and is used to draw students towards the target language (García, 2014). Moreover, our study indicates that students' languages do not exist prior to and independently of the task content; rather, multilingual practice is realised within the immediate context (Kloss \& Van Orden, 2009).

5 This form of repair is very rare in everyday conversations but is more typical for classroom interactions (Seedhouse, 2004, p. 35).

6 However, from the CA perspective, including such situations into the analysis is questionable. It is assumed that no reaction is also a type of behaviour in the classroom which can play a role in understanding language practices.

7 Also if we accept the presupposition that the use of English could be seen from the teacher's perspective as a mistake or an error, many scholars (e.g. Kleppin, 2010) suggest that not every mistake/error has to be repaired - treating mistakes/errors should be connected to the aim of each activity. 
If we look at the analysed situations from a pedagogical perspective, we can conclude that there was no evidence of a thought-out, conscious or consistent approach to using English in lessons. Consequently, the position of English in German lessons did not seem clear for the students. In some situations, using English was allowed and even supported, in some it was seen as a problem. This dichotomy even occurred within a single recorded lesson of a teacher ${ }^{8}$. Multiple studies indicate that teachers notice the linguistic repertoire of their students and its use, but they do not use them consistently for teaching (Göbel et al., 2010; de Angelis, 2011). In connection to such findings, our study suggests that the use of English in German lessons appears as a reaction to the ongoing communication situations and to the actual realisation of various teaching activities 9 .

A limitation however of this study is the fact that our data does not include interviews with the participating students and teachers. As a result of this circumstance some questions remain unanswered, such as the students' perceptions of the language policy set by the teacher in the classroom, and the nature of teachers' reactions to English language whether deliberate or intuitive. The conceptual limit of this study concerns the theoretical design of the study. While we subscribe to the heteroglossic approach to linguistic repertoires, in the context of this study we are forced to work with the discrete languages.

To sum up, using more languages simultaneously seems to be natural in language teaching. Furthermore, many scholars, see accepting and deliberately using more languages an advantage especially in second foreign language teaching (Hufeisen, 2010). This study, however, shows that in the L3 German classroom, L2 English is seen as a natural resource for learning and a natural part of communication, or a problem that needs correction. The definite approach seems to be more situation-linked than teacher-specific and consideration of consistency in approach may be required.

\section{References}

Bakhtin, M. M. (1981). The dialogic imagination: Four essays (Vol. 1). Austin: University of Texas Press.

Bär, M. (2009). Förderung von Mehrsprachigkeit und Lernkompetenz. Tübingen: Narr Francke Attempto Verlag.

Blackledge, A., \& Creese, A. (2009). Meaning-making as dialogic process: Official and carnival lives in the language classroom. Journal of Language, Identity, and Education, 8(4), 236-253.

Bonacina-Pugh, F. (2012). Researching 'practiced language policies': insights from conversation analysis. Language Policy, 11(3), 213-234.

Busch, B. (2010). School language profiles: Valorizing linguistic resources in heteroglossic situations in South Africa. Language and Education, 24(4), 283-294.

8 Of course, we also found some differences between teachers, but no teacher displayed consistent language policy in relation to English during teaching German.

9 For task-based communication in EFL teaching see e.g. Seedhouse (1999), for situational requirements of communication in FLT see e.g. Mondada and Doehler (2004). 
Busch, B. (2012a). Das sprachliche Repertoire oder Niemand ist einsprachig: Vorlesung zum Antritt der Berta-Karlik-Professur an der Universität Wien. Klagenfurt: Drava.

Busch, B. (2012b). The linguistic repertoire revisited. Applied Linguistics, 33(5), 503-523.

Bybee, J. L., \& Hopper, P. J. (2001). Introduction. In J. L. Bybee \& P. J. Hopper (Eds.), Frequency and the emergence of linguistic structure (Vol. 45) (pp. 1-3). Amsterdam: John Benjamins Publishing.

Canagarajah, S. (2012). Translingual practice: Global Englishes and cosmopolitan relations. Abingdon: Routledge.

Cashman, H., R. (2010). Conversation and interactional analysis. In L. Wei \& M. G. Moyer (Eds.), The Blackwell guide to research methods in bilingualism and multilingualism (pp. 275-296). Oxford: Blackwell Publishing.

Common European Framework of Reference for Languages: Learning, Teaching, Assessment. (2001). Council of Europe. Strasbourg: Oxford University press.

Coughlan, P., \& Duff, P. A. (1994). Same task, different activities: Analysis of a SLA task from an activity theory perspective. In J. P. Lantolf \& G. Appel (Eds.), Vygotskian approaches to second language research (pp. 173-193). Wesport, CT: Ablex.

Coulmas, F. (1985). Sprache und Staat. Studien zur Sprachplanung. Berlin, New York: De Gruyter.

Cummins, J. (2007). Rethinking Monolingual Instructional Strategies in Multilingual Classrooms. Canadian Journal of Applied Linguistics, 10(2), 221-40.

de Angelis, G. (2011). Teachers' beliefs about the role of prior language knowledge in learning and how these influence teaching practices. International Journal of Multilingualism, 8(3), 216-234.

Deppermann, A., \& Spranz-Fogasy, T. (2001). Aspekte und Merkmale der Gesprächssituation. In G. Antos, K. Brinker, W. Heinemann, \& S. Sager (Eds.), Text- und Gesprächslinguistik (pp. 1148-1161). Berlin: Walter de Gruyter.

Dewaele, J. M., \& Thirtle, H. (2009). Why do some young learners drop foreign languages? A focus on learner-internal variables. International Journal of Bilingual Education and Bilingualism, 12(6), 635-649.

Doughty, C. (1993). Fine-tuning of feedback by competent speakers to language learners. In G. Alatis (Ed.), Georgetown University Roundtable on Languagesa nd Linguistics (s. 96-108), Washington, D.C.: Georgetown University Press.

Drew, P., \& Heritage, J. (Eds.). (1992). “Analyzing talk at work: an introduction” In P. Drew \& J. Heritage (Eds.), Talk at work: Interaction in institutional settings (pp. 101-134), Cambridge: Cambridge University Press. Talk at Work: Interaction in Institutional Settings (pp. 3-65). Cambridge: Cambridge University Press.

Firth, A., \& Wagner, J. (1997). On discourse, communication, and (some) fundamental concepts in SLA research. The modern language journal, 81(3), 285-300.

Fitts, S. (2009). Exploring Third Space in a Dual-Language Setting: Opportunities and Challenges. Journal of Latinos and Education, 82(2), 87-104.

García, O. (2009). Bilingual Education in the 21st Century: A Global Perspective. Malden, MA: Wiley/Blackwell.

García, O. (2014). Multilingualism and language education. In C. Leung Brian \& V. Street (Eds.), The Routledge Companion to English (pp. 84-99). Abingdon: Routledge.

García, O., \& Kleifgen, J. A. (2010). Educating emergent bilinguals: Policies, programs, and practices for English language learners. Teachers College Press.

García, O., \& Wei, L. (2014). Translanguaging: Language, bilingualism and education. Houndmills: Palgrave.

Göbel, K., Vieluf, S., \& Hesse, H.-G. (2010). Die Sprachentransferunterstützung im Deutschund Englischunterricht bei Schülerinnen und Schülern unterschiedlicher Sprachlernerfahrung. In C. Allemann-Ghionda, P. Stanat, K. Göbel, \& Ch. Röhner (Eds.), Migration, Identität, Sprache und Bildungserfolg (pp. 101-122). Weinheim: Beltz.

Gumperz, J. J. (1964). Linguistic and social interaction in two communities. American Anthropologist, 66(6, Part 2), 137-153. 
Gumperz, J. J. (1982). Discourse strategies. Cambridge University Press.

Henry, A., \& Apelgren, B. M. (2008). Young learners and multilingualism: A study of learner attitudes before and after the introduction of a second foreign language to the curriculum. System, 36(4), 607-623.

Heritage, J. (2005). Conversation analysis and institutional talk. In K. L. Fitch \& R. E. Sanders (Eds.), Handbook of language and social interaction (pp. 103-147). Mahwah: Lawrence Erlbaum Associates.

Hufeisen, B. (2010). Bilingualität und Mehrsprachihkeit. In W. Hallet \& F. G. Königs (Eds.), Handbuch Fremdsprachendidaktik. Seelze-Velber: Friedrich Verlag.

Jacquemet, M. (2005). Transidiomatic Practices: Language and Power in the Age of Globalization. Language and Communication, 25, 257-77.

Jakisch, J. (2014). Lehrerperspektiven auf Englischunterricht und Mehrsprachigkeit. Zeitschrift für Interkulturellen Fremd- sprachenunterricht 19(1), 202-215.

Janík, T., Slavík, J., Mužík, V., Trna, J., Lokajíčková, V., Lukavský, J., ... Zlatníček, P. (2013). Kvalita (ve) vzdělávání: Obsahově zaměřený přístup ke zkoumání a zlepšování výuky. Brno: Masarykova univerzita.

Kasper, G. (2004). Participant orientations in German conversation for learning. The Modern Language Journal, 88(4), 551-567.

Klein, W. (1998). The contribution of second language acquisition research. Language learning, 48(4), 527-549.

Kleppin, K. (2010). Fehleranalyse und Fehlerkorrektur. Deutsch als Fremd-und Zweitsprache. Ein internationales Handbuch, 1, 1060-1072.

Kloss, H. \& Van Orden, G. (2009) "Soft-Assembled Mechanisms for the Grand Theory," in J.P. Spencer, M. Thomas \& J. McClelland (Eds.), Toward a New Grand Theory of Development? Connectionism and Dynamics Systems Theory Reconsidered (pp. 253-267). Oxford: Oxford University Press.

Königs, F. G. (2010). Zweitsprachenerwerb und Fremdsprachenlernen: Begriffe und Konzepte. In C. Fandrych, B. Hufeisen, H.-J. Krumm, \& C. Riemer (Eds.), Deutsch als Fremd- und Zweitsprache (pp. 754-763). Berlin: De Gruyter.

Koshik, I. (2002). Designedly incomplete utterances: A pedagogical practice for eliciting knowledge displays in error correction sequences. Research on language and social interaction, 35(3), 277-309.

Krumm, Hans Jürgen (2015). „Organisiertes Schulversagen - oder: Anforderungen an die Schule in der Einwanderungsgesellschaft. “ In: İnci Dirim (Ed.), Impulse für die Migrationsgesellschaft. Bildung, Politik und Religion (pp. 280-293). Münster: Waxmann.

Krzyżanowski, M., \& Wodak, R. (2011). Political strategies and language policies: the European Union Lisbon strategy and its implications for the EU's language and multilingualism policy. Language Policy, 10(2), 115-136.

Levinson, B. A., Sutton, M., \& Winstead, T. (2009). Education policy as a practice of power theoretical tools, ethnographic methods, democratic options. Educational Policy, 23(6), 767-795.

Lewis, G., Jones, B., \& Baker, C. (2012). Translanguaging: Origins and development from school to street and beyond. Educational Research and Evaluation, 18(7), 641-654.

van Lier, L. (1988). The classroom and the language learner: Ethnography and second-language classroom research. London: Longman.

Long, M. H. (1981). Input, interaction, and second language acquisition. Annals of the New York academy of sciences, 379(1), 259-278.

Long, M. H. (1996). The role of the linguistic environmentin second language acquisition. In W. C. Ritchie \& T. K. Bhatia (Eds.), Handbookof languageacquisition: Secondlanguageacquisition II (pp. 413-468). New York: Academic.

Lyster, R. (1998). Negotiation of form, recasts, and explicit correction in relation to error types and learner repair in immersion classrooms. Language learning, 48(2), 183-218.

Lyster, R., \& Ranta, L. (1997). Corrective feedback and learner uptake: Negotiation of form in communicative classrooms. Studies in Second Language Acquisition, 9(1), 37-66. 
Mackey, A., \& Philp, J. (1998). Conversational interaction and second language development: Recasts, responses, and red herrings? The Modern Language Journal, 82(3), 338-356.

Makalela, L. (2015). Moving out of linguistic boxes: The effects of translanguaging strategies for multilingual classrooms. Language and education, 29(3), 200-217.

Markee, N., \& Kasper, G. (2004). Classroom talks: An introduction. The Modern Language Journal, 88(4), 491-500.

Mehan, H. (1979). Learning lessons. Cambridge, London: Harvard University Press.

Mondada, L., \& Doehler, S. P. (2004). Second language acquisition as situated practice: Task accomplishment in the French second language classroom. The Modern Language Journal, 88(4), 501-518.

Multilingualism: an asset for Europe and a shared commitment. (2008). Brussels: European Commission.

Ortega, L. (2013). SLA for the 21st century: Disciplinary progress, transdisciplinary relevance, and the bi/multilingual turn. Language Learning, 63, 1-24.

Otsuji, E., \& Pennycook, A. D. (2010) Metrolingualism: Fixity, Fluidity and Language in Flux. International Journal of Multilingualism, 7(3), 240-54.

Pavlenko, A. (1998). Second Language Learning by Adults: Testimonies of Bilingual Writers. Issues in Applied Linguistics, 9(1), 3-19.

Phillipson, R. (2009). Linguistic imperialism continued. London: Routledge.

Pomerantz, A. (1978). Compliment responses: Notes on the co-operation of multiple constraints. In G. Jefferson \& J. Schenkein (Eds.) Studies in the organization of conversational interaction (pp. 79-112). New York: Academic Press.

Riemele, R. (2002). Videograph. Multimedia-Player zur Kodierung von Videos. Kiel: IPN.

Schütze, F. (1987). Situation. In U. Ammon, N. Dittmar, \& K. J.Mattheier, (Eds.), Soziolinguistik (pp. 157-164). Berlin: de Gruyter.

Seedhouse, P. (1999). Task-based interaction. ELT Journal, 53(3), 149-156.

Seedhouse, P. (2004). The interactional architecture of the language classroom: A conversation analysis perspektive. New Jersey: Wiley-Blackwell.

Selinker, L. (1972). Interlanguage. IRAL-International Review of Applied Linguistics in Language Teaching, 10(1-4), 209-232.

Selting, M., Auer, P., Barth-Weingarten, D., Bergmann, J. R., Bergmann, P., Birkner, K., ... Hartung, M. (2009). Gesprächsanalytisches Transkriptionssystem 2 (GAT 2). Gesprächsforschung - Online-Zeitschrift zur verbalen Interaktion, 10, 353-402.

Sert, O., \& Walsh, S. (2013). The interactional management of claims of insufficient knowledge in English language classrooms. Language and Education, 27(6), 542-565.

Stritikus, T. T. (2003). The interrelationship of beliefs, context, and learning: The case of a teacher reacting to language policy. Journal of language, identity and education, 2(1), 29-52.

Ten Have, P. (2007). Doing conversation analysis. London: Sage.

Vetter, E. (2013). Sprachliche Bildung macht den Unterschied. Sprachen in schulischen Lehrkontexten. In E. Vetter (Ed.), Professionalisierung für sprachliche Vielfalt. Perspektiven für eine neue LehrerInnenbildung (pp. 238-258). Hohengehren: Schneider.

Mgr. Miroslav Janík, Ph.D.

Institute for Research in Education / Department for German Language and Literature

Faculty of Education

Masaryk University

Pořicí 7/9, Brno

Czech Republic

mjanik@ped.muni.cz 